\title{
Chemical characterization of oil from four Avocado varieties cultivated in Morocco ${ }^{\text {is }}$
}

\author{
Chaimae Nasri ${ }^{1}$, Yasmina Halabi ${ }^{1}$, Hicham Harhar ${ }^{1, *}$, Faez Mohammed $^{2, *}$, Abdelkabir Bellaouchou ${ }^{1}$, \\ Abdallah Guenbour ${ }^{1}$ and Mohamed Tabyaoui ${ }^{1}$ \\ ${ }^{1}$ Laboratory of Materials, Nanotechnology, and Environment LMNE, Faculty of Sciences, Mohammed V University of Rabat, BP 1014, \\ Rabat, Morocco \\ ${ }^{2}$ School of Environmental Sciences, University of Guelph, 50 Stone Road E, Guelph ON N1G 2W1, Canada
}

Received 23 November 2020 - Accepted 2 February 2021

\begin{abstract}
The notable growth in the use of avocado oil in the nutritional and cosmetic field was the main objective to valorize the oil production of important varieties of avocados existing in Morocco by analyzing its chemical composition in fatty acids, sterols, tocopherols and its physico-chemical properties. Oleic acid is the main fatty acid in the oil; they constitute between 50 and $65 \%$ of the total fatty acids. The study of the unsaponifiable fraction revealed that avocado oil contains $3259.9-5378.8 \mathrm{mg} / \mathrm{kg}$ sterols and $113.13-$ $332.17 \mathrm{mg} / \mathrm{kg}$ tocopherols. Chemo-metric tools were employed in manner optimization, such as principal component analysis, agglomerative hierarchical clustering, analysis of variance, and classification trees using Chi-squared Automatic Interaction Detector. Chemo-metric tools revealed a difference in the composition of fatty acid, sterols, and tocopherol of avocado oil samples. This difference resulted from a variety of avocado fruits. Agglomerative Hierarchical Clustering (AHC) method was efficient distinguishing avocado oil samples based on fruit variety using fatty acids, tocopherols, sterol compositions and total sterol. Principal component analysis (PCA) method allowed the distinction the set avocado oil dataset based on fruit varieties, supplied a correct discrimination rate of $95.44 \%$ for avocado fruit varieties using the fatty acid. Chi-squared Automatic Interaction Detector (CHAID) carried out using the same variables, also provided an acceptable classification rate of $50 \%$ for avocado fruit varieties using the total tocopherol content. Besides, a comparative study of the physico-chemical properties in terms of acidity index, saponification index, iodine index, chlorophylls, carotenoids, and methyl and ethyl esters was performed.
\end{abstract}

Keywords: Avocado oil / chemical composition / chemo-metric tools / varieties / oleic acid

Résumé - Caractérisation chimique de l'huile de quatre variétés d'Avocat cultivées au Maroc. La croissance notable de l'utilisation de l'huile d'avocat dans le domaine nutritionnel et cosmétique était l'objectif principal pour valoriser la production d'huile d'importantes variétés d'avocats existant au Maroc en analysant sa composition chimique en acides gras, stérols, tocophérols et ses propriétés physicochimiques. L'acide oléique est le principal acide gras de l'huile; ils constituent entre 50 et $65 \%$ des acides gras totaux. L'étude de la fraction insaponifiable a révélé que l'huile d'avocat contient 3259,9-5378,8 mg/kg de stérols et $113,13-332,17 \mathrm{mg} / \mathrm{kg}$ de tocophérols. Des outils chimiométriques ont été utilisés pour l'optimisation des méthodes, tels que l'analyse en composantes principales (ACP), La classification ascendante hiérarchique (CAH), l'analyse de variance (ANOVA) et les arbres de classification utilisant le détecteur automatique d'interaction du chi carré (CHAID). Les outils chimiométriques ont révélé une différence dans la composition des acides gras, des stérols et du tocophérol des échantillons d'huile d'avocat. Cette différence est due à une variété d'avocats. La méthode CAH s'est avérée efficace pour distinguer les échantillons d'huile d'avocat en fonction de la variété de fruit, en utilisant les acides gras, les tocophérols, les compositions de stérols et le stérol total. La méthode d'analyse en composantes principales

\footnotetext{
it Contribution to the Topical Issue "Minor oils from atypical plant sources / Huiles mineures de sources végétales atypiques".

*Correspondences: hichamoo79@yahoo.fr; faez@uoguelph.ca
} 
a permis de distinguer l'ensemble des données sur l'huile d'avocat en fonction des variétés de fruits, et a fourni un taux de discrimination correct de 95,44\% pour les variétés de fruits d'avocat utilisant la composition en acides gras. La méthode Chi-squared Automatic Interaction Detector, réalisée à l'aide des mêmes variables, a également fourni un taux de classification acceptable de $50 \%$ pour les variétés d'avocats utilisant la teneur totale en tocophérols. En outre, une étude comparative des propriétés physico-chimiques en termes d'acidité, d'indice de saponification, d'indice d'iode, de chlorophylles, de caroténoïdes et d'esters méthyliques et éthyliques a été réalisée.

Mots clés : Huile d'avocat / composition chimique / outils chimiométriques / acide oléique / variétés

\section{Introduction}

The Avocado (Persea Americana Mill.) is from the Lauraceae family (Krumreich et al., 2018). Avocado is one of the most important crops in the tropical and subtropical countries of the world (Ojewole et al., 2007; Indriyani et al., 2016). In Morocco, most of the crops are located in the northwestern coastal strip of the country, between the south of Rabat and Tangier (Denis, 2008). It's mainly consumed in the form of fresh fruit for its good nutritional value (HurtadoFernandez et al., 2018).

Avocado is a major market worldwide, alongside its use in the cosmetics, edible oil and food processing industries (Swisher, 1988; Athar and Nasir, 2005; Indriyani et al., 2016). The pulp of this fruit is known for its high lipid content similar to that of olive oil, containing mainly fatty acid (Tango et al., 2004) as well as minerals such as iron, magnesium, phosphorus, and potassium (Goff and Klee, 2006). Compared to other sources of vegetable oil, the major fatty acid of avocado oil is oleic and linoleic acid. Oleic acid is supposed to present modulatory effects in a extensive physiological functions, while some studies also suggest a beneficial effect on cancer, autoimmune and inflammatory diseases, besides its ability to facilitate wound healing (Sales-Campos et al., 2013). Linolenic acid is an essential fatty acid needed for human health. it has been reported to have cardiovascular-protective, anti-cancer, neuro-protective, anti-osteoporotic, anti-inflammatory, and antioxidative effects (Kim et al., 2014). These fats are believed to have incredible health benefits as they help increase levels of HDL-cholesterol (the good cholesterol) and decreasing levels of LDL-cholesterol (the bad cholesterol), both of which significantly reduce the risk of cardiovascular disease (Lunn and Theobald, 2006).

Avocado is also rich in unsaponifiable compounds such as sterols, mainly $\beta$-sitosterol, vitamins, carotenoids, tocopherols, and the phenolic compounds are of significant interest, for their antioxidant and anti-inflammatory properties (Kosińska et al., 2012; Zhang et al., 2013).

In addition to its high content of good fats, avocado pulp also contains several hundred phytochemical molecules that may play a role in cancer prevention ( $\mathrm{Lu}$ et al., 2005). In addition to certain molecules that are widespread in the plant world such as flavonoids (quercetin, luteolin, apigenin, etc.) or coumarins (scopoletine), avocados have the particularity of containing alkanols, a class of fat-soluble molecules that show a great inhibitory activity on cancer cells (Lu et al., 2005). For example, several studies have shown that avocado extracts containing some of these molecules (persine, isopersine, persenone) stopped the growth of cancer cells from several different types of cancer, including those of the mouth, breast, prostate, and lung (Lu et al., 2005).

This work aims at evaluating the effects of different avocado varieties on oil yield, chemical composition and physico-chemical characteristics, using chemo-metric tools. In order to identify the most promising varieties for fresh sale or transformation.

\section{Material and methods}

\subsection{Plant material}

The four avocado fruit varieties (Ettinger, Fuerte, Hass and Reed) was harvested in the region of Rabat-SaléKenitra. The sampling was done in January 2019. The avocado pulp was sorted and then dried in the oven overnight at $45^{\circ} \mathrm{C}$. The plant material, once dried, it is reduced to powder in a blender and stored in bags.

$50 \mathrm{~g}$ of ground dried avocado pulp were extracted in a Soxhlet extractor for $8 \mathrm{~h}$ using $250 \mathrm{~mL}$ of n-hexane (analytical grade). This solvent was removed at $50{ }^{\circ} \mathrm{C}$ under reduced pressure using a rotary evaporator. The extracted oils were subsequently placed in brown glass bottles and stored at $4{ }^{\circ} \mathrm{C}$.

\subsection{Physical and chemical analysis of crude oil}

The oil yield was measured according to ISO 659 (2009), Official Methods of the American Oil Chemists' Society were used for the determination of iodine value (method Cd 1-25), acid value (method $\mathrm{Ca} 5 \mathrm{a}-40$ ), and saponification value (method Cd 3-25) (AOCS, 1998). Acid value (AV) was determined by titration of a solution of oil in ethanol with ethanolic $\mathrm{KOH}$ and is expressed as $(\mathrm{mg} \mathrm{KOH} / \mathrm{g}$ oil). Iodine value was expressed as ( $\mathrm{g}$ of $\mathrm{I}_{2} / 100 \mathrm{~g}$ of oil), It was experimentally determined by treatment with Wijs reagent followed by titration of the iodine excess with $\mathrm{Na}_{2} \mathrm{~S}_{2} \mathrm{O}_{3}$ and Saponification value was determined by titration of a solution of oil in $0.1 \mathrm{~N}$ ethanolic $\mathrm{KOH}$ with $0.5 \mathrm{M} \mathrm{HCl}$, it was expressed as (mg $\mathrm{KOH} / \mathrm{g}$ of oil)

Carotenoid and chlorophyll compounds were determined in cyclohexane at 470 and $670 \mathrm{~nm}$, respectively, using the specific extinction coefficients, according to the method of Mínguez-Mosquera et al. (1991) et Gharby et al. (2018).

Fatty acids alkyl esters were determined by gas chromatography (GC-FID) according to the method reported by Rabeh et al. (2018). $500 \mathrm{mg}$ of avocado oil was weighed and added with $0.225 \mathrm{~mL}$ of a $0.02 \% \mathrm{w} / \mathrm{v}$ of a methyl heptadecanoate 
Table 1. Physical characteristics of four varieties of avocado fruit.

\begin{tabular}{|c|c|c|c|c|c|c|}
\hline & Shape & $\begin{array}{l}\text { Average weight } \\
(\mathrm{g})\end{array}$ & Skin & Pulp color & Seed & $\begin{array}{l}\text { Size } \\
(\mathrm{cm})\end{array}$ \\
\hline Ettinger & $\begin{array}{l}\text { Pear, longer } \\
\text { and broad neck }\end{array}$ & $150-300$ & $\begin{array}{l}\text { Smooth, medium } \\
\text { gloss and green }\end{array}$ & Green & $\begin{array}{l}\text { Medium to large, } \\
\text { conical with pointed apex }\end{array}$ & $12-15$ \\
\hline Fuerte & Pear & $250-400$ & Green and slightly pebbled & Pale green & Medium & $10-12$ \\
\hline Hass & Ovale & $120-200$ & Dark green and bumpy & Pale green & Small & $6.5-9$ \\
\hline Reed & Round & $300-400$ & Medium to thick and easy peeling & Green & Medium to large & $10-11$ \\
\hline
\end{tabular}

solution in n-heptane, used as internal standard. The obtained solution was transferred into the chromatographic column (internal diameter $15 \mathrm{~mm}$, lenght $40 \mathrm{~cm}$, fitted with a suitable stopcock). Using a mixture of $n$-hexane/ethyl ether (99:1) For elution. The collected fraction, containing alkyl esters, was transferred into a rotary evaporator to remove solvents. The residue was redissolved in $2 \mathrm{~mL}$ of n-heptane. GC-FID analyses were performed on a $7890 \mathrm{GC}$ (Agilent), equipped with a HP-5 column $(15 \mathrm{~m} \times 0.32 \mathrm{~mm}$ i.d. $\times 0.25 \mu \mathrm{m})$.

\subsection{Chemical composition of crude oil}

For the fatty acid composition determination, the methyl esters were analyzed according to ISO 5508 (1990), a CP-Wax $52 \mathrm{CB}$ column $(30 \mathrm{~m} \times 0.25 \mathrm{~mm}$ i.d. $)$ was used, the carrior gas used was helium (flow rate $1 \mathrm{~mL} / \mathrm{mn}$ ). Initial oven temperature was set at $170^{\circ} \mathrm{C}$; injector temperature $200^{\circ} \mathrm{C}$; detector temperature $230^{\circ} \mathrm{C}$. Injected quantity was $1 \mathrm{uL}$. Sterol composition was determined according to ISO 6799 (1991), after trimethylsilylation of the crude sterol fraction using a Varian 3800 instrument equipped with a VF-1 ms column $(30 \mathrm{~m}$ and $0.25 \mathrm{~mm}$ i.d.) and using helium (flow rate $1.6 \mathrm{~mL} / \mathrm{mn}$ ) as carrier gas. Column temperature was isothermal at $270{ }^{\circ} \mathrm{C}$, injector and detector temperature was $300{ }^{\circ} \mathrm{C}$. Injected quantity was $1 \mathrm{uL}$. while the tocopherols was separated and quantified by HPLC, according to ISO 9936 (2006). The HPLC used for this study was Shimadzu CR8A instruments (Champ sur Marne, France) equipped with a C18-Varian column $(25 \mathrm{~cm} \times 4 \mathrm{~mm}$; Varian Inc., Middelburg, The Netherlands). Detection was performed using a fluorescence detector (excitation wavelength $290 \mathrm{~nm}$, detection wavelength $330 \mathrm{~nm}$ ). Eluent used was a 99:1 isooctane/isopropanol $(\mathrm{V} / \mathrm{V})$ mixture, flow rate of $1.2 \mathrm{ml} / \mathrm{min}$. Chromatographic peaks were identified and quantified using $\alpha$-tocopherol standards.

\subsection{Statistical analysis}

Analysis of variance (ANOVA) was performed by the software IBM SPSS Statistics 21, for the checking of the statistical significance by Tukey tests at a confidence level of $95.0 \%$, as well as, and the results were presented as means \pm standard error of the mean. Multivariate statistical treatments, hierarchical agglomerative clustering, principal component analysis, and discrimination trees were carried out by using the XLSTAT version 2019.

\section{Results and discussion}

\subsection{Physical characteristics}

As for the physical characteristics to identify the different varieties of the avocado fruit, each is popular for its shape, color, skin, and size (Salunkhe and Kadam, 1995). Table 1 presents the characteristics of the four selected varieties.

The results, as summarized in Table 1, are very useful to recall the main characteristics of the fruits of each briefly. The color of the skin varies from light green to dark green. The variety of Hass becomes purplish-black when ripe (Ojewole and Amabeoku, 2006).

The Ettinger and Fuerte varieties are mainly pear-shaped, while the Hass is oval, and the Reed is round. The four varieties of Avocado have different skin structures. Some varieties have smooth skin (Ettinger), while others are grainy or granular skin (Fuerte and Hass).

\subsection{Physical and chemical parameters}

Avocado oil extracted from all the pulp samples had a yellowish-green color and a characteristic hazelnut smell. The investigated avocado fruit contained relatively high amounts of oil in comparison with other vegetable oils, like pumpkin seed oil (Boujemaa et al., 2020) or cactus oil (Gharby et al., 2020). The "Ettinger" fruit, in particular, contains the highest oil level $(72.54 \%)$. These amounts were relatively high in comparison to maximal values reported from Chile $(25.8 \%)$ (Olaeta et al., 1986); South Africa (40.0\%) (Pearson, 1975) and Brazil (25.5\%) (Tango et al., 1969).

However, the oil content of the other avocado varieties was lower than that of Ettinger (Fuerte, Hass and Reed $44.69 \%$, $55.71 \%$ and $56.5 \%$ respectively) (Tab. 2 ).

Table 2 shows the data on some physicochemical characteristics of pulp oils from the four varieties. The free fatty acids in a sample are measured using the acid value assay; in this case, from the pulp oil of the four varieties studied. The results have demonstrated a significant difference $(p<0.05)$ between the varieties. The values were 1.4, 2.6, 1.9, and $2.4 \mathrm{mg}$ $\mathrm{KOH} / \mathrm{g}$ oil for Ettinger, Fuerte, Hass, and Reed varieties, respectively. These values are higher than those reported previously for the Fuerte variety $(1.23 \mathrm{mg} / \mathrm{g}$ ) (Bora et al., 2001), and avocados grown in Mexico (1.46 mg/g) (Moreno et al., 2003). Also, the saponification value of the Hass variety (231.41 mg KOH/g oil) was higher than the values reported previously for avocado oil as it reached 178 (Bora et al., 2001), 
Table 2. Physico-chemical parameters of oil from four avocado varieties.

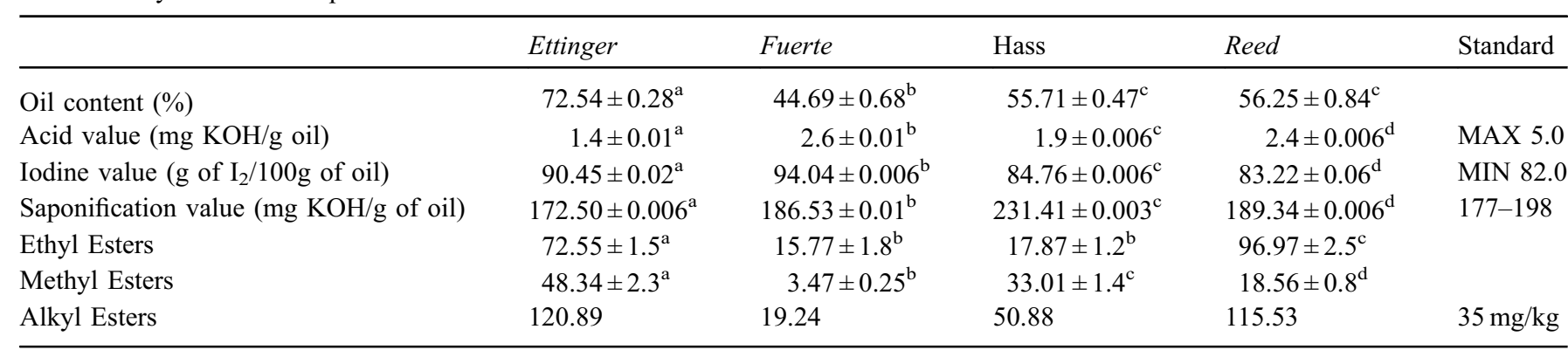

Means of three determinations \pm standard deviation. Values followed by the same small letters in a row are not significantly different at $p<0.05$ according to ANOVA. Tukey HSD test.

Table 3. Determination of chlorophyll and carotenoid in oil from four avocado varieties.

\begin{tabular}{lllll}
\hline & Ettinger & Fuerte & Hass & Reed \\
\hline Chlorophyll (mg / $/ \mathrm{kg})$ & $0.54 \pm 0.006^{\mathrm{a}}$ & $1.63 \pm 0.003^{\mathrm{b}}$ & $1.04 \pm 0.003^{\mathrm{c}}$ & $0.83 \pm 0.009^{\mathrm{d}}$ \\
Carotenoid $(\mathrm{mg} / \mathrm{kg})$ & $0.77 \pm 0.05^{\mathrm{a}}$ & $0.40 \pm 0.03^{\mathrm{b}}$ & $0.56 \pm 0.03^{\mathrm{c}}$ & $0.35 \pm 0.01^{\mathrm{d}}$ \\
\hline
\end{tabular}

Means of three determinations \pm standard deviation. Values followed by the same small letters in a row are not significantly different at $p<0.05$ according to ANOVA. Tukey HSD test.

175-190 (Medina 1980), and $178 \mathrm{mg} \mathrm{KOH/g}$ oil (Soares et al., 1992).

The iodine values of pulp oil of the four varieties varied from 83.22 to $94.04 \mathrm{~g}$ of $\mathrm{I}_{2} / 100 \mathrm{~g}$ of oil, and these values are higher to those reported by Bora et al. (2001) and Medina (1980). Still, they are inside the range of $82-95 \mathrm{~g}$ of $\mathrm{I}_{2} / 100 \mathrm{~g}$ of oil reported by Moreno et al. (2003).

Ethyl esters assay was imposed by the International Olive Council as a quality criterion in oil investigations. As a result, a standard was set for different types of oils to be respected by manufacturers (Beltran et al., 2015). Currently, the European commission regulation suggested a limit for the ethyl esters content of $35 \mathrm{mg} / \mathrm{kg}$ (oil) (COI, 2012). Like olives, avocados contain a certain amount of sugars that transform into alcohol through fermentation. An important indicator of oil quality is free fatty acids; these free fatty acids react with the methyl and ethyl alcohols (R'-OH) to form fatty acid ethyl esters (FAEE) and fatty acid methyl esters (FAME) (Rabeh et al., 2018).

The lowest content of fatty acid alkyl esters FAAEs (FAEEs + FAMEs) was observed in Fuerte $(19.24 \mathrm{mg} / \mathrm{kg})$ and the highest in Ettinger $(120.89 \mathrm{mg} / \mathrm{kg})$. In general, studies about alkyl esters in avocado oil are still an unfamiliar world. Three essential factors could affect the content of such studies, ripening stage, post-harvest storage conditions and oil filtration (Rabeh et al., 2018).

\subsection{Determination of oil pigments}

Table 3 shows that the Fuerte has the highest content of chlorophyll $(1.63 \mathrm{mg} / \mathrm{kg})$, followed by Hass and Reed which contain doses of $1.04 \mathrm{mg} / \mathrm{kg}$ and $0.83 \mathrm{mg} / \mathrm{kg}$ respectively, while Ettinger is the variety with the lowest chlorophyll value $(0.54 \mathrm{mg} / \mathrm{kg})$. The chlorophyll content of the pulp of the avocados of the four varieties was higher than that reported by
Krumreich et al. (2018) (0.18 mg.kg $\left.{ }^{-1}\right)$. However, it was lower than that reported by Wang et al. (2010) $(28.7 \mathrm{mg} / \mathrm{kg})$. Chlorophyll does not contribute to oil stability but it can act as a sensitizer for photo-oxidation to occur. Therefore, it is important to store the oil away from light (Rukmini and Raharjo, 2010).

The consumption of carotenoids may bring health benefits because lutein helps reduce macular degeneration due to aging (Koh et al., 2004). In the market, this type of oil has high benefits, especially among people interested in the field of cuisine. In this case, the concentration and nature of the oils are important determinants of quality and, therefore, marketing. Avocados contain important amounts of carotenoids in their oil that are believed to be potential anti-carcinogenic agents (Mooz et al., 2012). Ettinger variety has the highest content of Carotenoids $(0.77 \mathrm{mg} / \mathrm{kg})$, followed by Hass and Fuerte, which contain $0.56 \mathrm{mg} / \mathrm{kg}$ and $0.40 \mathrm{mg} / \mathrm{kg}$ of carotenoids respectively, while Reed present the lowest carotenoids value $(0.35 \mathrm{mg} / \mathrm{kg})$. Our values were lower than those found by Mardigan et al. (2019) for other varieties cultivated in Brazil $(2.7 \mathrm{mg} / \mathrm{kg})$.

According to Ashton et al. (2006) all carotenoids are present in unripe avocados, but as they ripen, all carotenoids other than lutein decrease to near-zero. The fruit used in this study were mature; therefore, many of the minor carotenoids would be unlikely to be extracted into the oils. In cold-pressed olive oil (similarly to the extraction of avocado oil), the lutein concentrations ranged from 0.2 to $3.9 \mu \mathrm{g} \cdot \mathrm{g}^{-10}$ (Psomiadou and Tsimidou, 2001).

\subsection{Fatty acid composition}

Several studies have reported the fatty acid composition of avocado oil, where oleic acid was reported to be the major acid. 
Table 4. Fatty acid composition of oil from four avocado varieties.

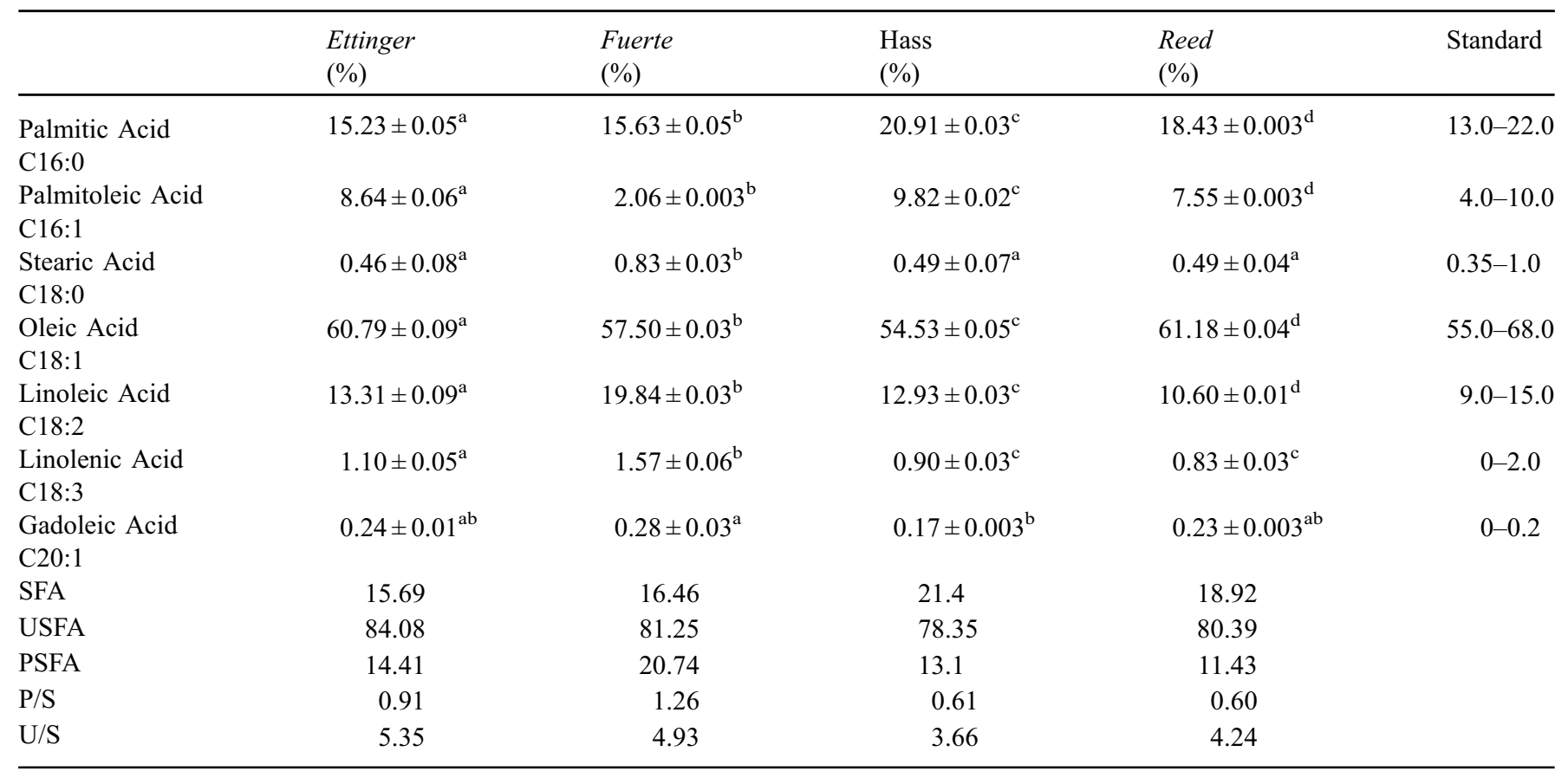

Means of three determinations \pm standard deviation. Values followed by the same small letters in a row are not significantly different at $p<0.05$ according to ANOVA. Tukey HSD test.

$\mathrm{SFA}=$ saturated fatty acids; USFA = unsaturated fatty acids; PUFA = polyunsaturated fatty acids; $\mathrm{P} / \mathrm{S}=$ Polyunsaturated fatty acid/Saturate fatty acid ratio; $\mathrm{U} / \mathrm{S}=$ Unsaturated fatty acid/Saturate fatty acid ratio.

This fact supports the consumption of this oil for its beneficial health effect as oleic acid is related to the reduction of diabetes, oxidative stress and to relieve cardiovascular disease effects (Ortiz-Avila et al., 2013; Carvajal-Zarrabal et al., 2014). Table 4 shows the results obtained.

The avocado oil is rich in oleic, palmitic, linoleic, and palmitoleic acids, while stearic acid is present in tiny amounts. The Reed variety reported the highest amount of oleic acid $(61.18 \%)$ amongst all studied varieties. On the other hand, the Hass variety recorded the lowest oleic acid amount $(54.53 \%)$ which differs from the findings of Lozano et al. (1985), where oleic acid accounted for $65-80 \%$ in Mediterranean avocado oil. Palmitic and linoleic acid are in second and third places with different proportions depending on the variety. The fatty acid composition found is comparable to those of palm and olive oils as reported in previous studies (Gharby et al., 2013, 2014). When it comes to unsaturated fatty acids, it is the Ettinger that has the highest proportion with a value of $84.04 \%$.

The Fuerte in our case reported values of $57.5 \%$ for oleic acid, followed by linoleic and palmitic acids, with values of $19.84 \%$ and $15.63 \%$, respectively. These findings are similar to those previously reported for avocado oil in other countries, where oleic acid was found to be at about $45.9-54.5 \%$, followed by palmitic acid with 19.7-20.0\%, and linoleic acid with 5.7-12.5\% (Bora et al., 2001; Azizi and Najafzadeh, 2008). A high ratio of PUFA/SFA (recommended minimum value of 0.4 ) is linked to beneficial health effects especially for cardiovascular diseases (Wood et al., 2004). Those values were 0.91, 1.26, 0.61, and 0.60 for Ettinger, Fuerte Hass, and Reed, respectively, values higher than 0.4 show the nutritional value of avocado oil. The Table 4 shows also the ratio of unsaturated to saturated fatty acids (PUFA/SFA). The values of this ratio were 5.35, 4.93, 3.66, and 4.24 for Ettinger, Fuerte Hass, and Reed, respectively. These values were close to those found by Vekiari et al., (2004) for the same varieties from Greece. For avocado oil the amount of PUFA is about five folds of SFA, which is also true for Greece's avocado oil, as reported by Vekiari et al. (2004).

\subsection{Sterol composition}

Sterols are among the essential components of the unsaponifiable fraction. They are antioxidant compounds widely distributed in plants that give the oils a great nutritional value (Youssef et al., 2010).

The results presented in Table 5 allowed us to determine the total sterol contents present in our oils quantitatively. Sterol identification assay is one of the most reliable ways for adulteration and authenticity detection for most vegetal oils. In all the studied varieties, the major sterols found are $\beta$-sitosterol, $\Delta 5$-avenasterol, and campesterol, while cholesterol, stigmasterol are present in small amounts (Tab. 5).

The Codex Alimentarius standard stipulates that total sterols for Avocado oils must be above $2437 \mathrm{mg} \cdot \mathrm{kg}^{-1}$ (Codex Alimentarius, 2019). In this study, all varieties reported a total sterol concentration above the previously cited limit, with $3259.9 \mathrm{mg} \cdot \mathrm{kg}^{-1}$ being the lowest value found for the Ettinger. In contrast, Fuerte reported the highest content with 
Table 5. Sterol composition of oil from four avocado varieties.

\begin{tabular}{|c|c|c|c|c|c|c|}
\hline & $\begin{array}{l}\beta \text {-sitosterol } \\
(\mathrm{mg} / \mathrm{kg})\end{array}$ & $\begin{array}{l}\Delta 5 \text {-avenasterol } \\
(\mathrm{mg} / \mathrm{kg})\end{array}$ & $\begin{array}{l}\text { Campesterol } \\
(\mathrm{mg} / \mathrm{kg})\end{array}$ & $\begin{array}{l}\text { Cholesterol } \\
(\mathrm{mg} / \mathrm{kg})\end{array}$ & $\begin{array}{l}\text { Stigmasterol } \\
(\mathrm{mg} / \mathrm{kg})\end{array}$ & $\begin{array}{l}\text { Total sterol } \\
(\mathrm{mg} / \mathrm{kg})\end{array}$ \\
\hline Ettinger & $2686.81 \pm 0.03^{\mathrm{a}}$ & $265.68 \pm 0.03^{\mathrm{a}}$ & $155.82 \pm 0.01^{\mathrm{a}}$ & $17.28 \pm 0.03^{\mathrm{a}}$ & $19.23 \pm 0.05^{\mathrm{a}}$ & $3259.90 \pm 0.04^{\mathrm{a}}$ \\
\hline Hass & $3650.01 \pm 0.03^{\mathrm{b}}$ & $311.56 \pm 0.06^{\mathrm{c}}$ & $245.14 \pm 0.01^{\mathrm{b}}$ & $5.68 \pm 0.03^{\mathrm{b}}$ & $27.09 \pm 0.03^{\mathrm{ab}}$ & $4369.7 \pm 0.05^{\mathrm{c}}$ \\
\hline Reed & $2998.13 \pm 0.03^{\mathrm{c}}$ & $144.48 \pm 0.05^{\mathrm{d}}$ & $263.28 \pm 0.04^{\mathrm{c}}$ & $10.35 \pm 0.04^{\mathrm{c}}$ & $3.21 \pm 0.003^{\mathrm{c}}$ & $3567.5 \pm 0.09^{\mathrm{d}}$ \\
\hline
\end{tabular}

Means of three determinations \pm standard deviation. Values followed by the same small letters in a column are not significantly different at $p<0.05$ according to ANOVA. Tukey HSD test.

$5378.8 \mathrm{mg} \cdot \mathrm{kg}^{-1}$ (not exceed the limit of Codex of $6200 \mathrm{mg} \cdot \mathrm{kg}^{-1}$ ) (Codex Alimentarius, 2019).

Those values are higher than those of olive oil (Gharby et al., 2012). Its antioxidant activity and health-promoting effects have already been mentioned (Moreau et al., 2002; Yoshida and Niki, 2003); the Fuerte oil seems to have better quality when it comes to sterols.

$\beta$-sitosterol is the most abundant sterol in avocado oil, the same sterol was found to be the major sterol for olive oil (Gharby et al., 2012). Fuerte recording the highest amount with $4499.90 \mathrm{mg} \cdot \mathrm{kg}^{-1}$, and the lowest concentration was Ettinger with $2686.81 \mathrm{mg} \cdot \mathrm{kg}^{-1}$. Previous studies have also reported that $\beta$-sitosterol represented more than $75 \%$ of the overall total sterols content (Boskou, 2006; Plaza et al., 2009). The obtained results are also similar to the findings reported previously (Phillips et al., 2005). Awad et al. (2003) discussed the health benefits of $\beta$-sitosterol, it reduce plasma cholesterol and prevent different types of cancer.

Regarding the fact that all avocado fruits were harvested at the same stage of maturity, the same region and the observed differences might be due to variety, climate, or soil type.

The $\Delta 5$-avenasterol content for the Fuerte was the highest (327.03 mg. $\mathrm{kg}^{-1}$ ), while the Reed recorded the lowest value (144.48 mg. $\left.\mathrm{kg}^{-1}\right)$. These values are lower than those reported by Berasategi et al. (2012), and in agreement with the results obtained by Flores et al. (2019). In fact, $\Delta 5$-avenasterol can exhibit an important antioxidant ability and can improve the oxidative stability of olive oils at high temperature or even under frying conditions (Wang et al., 2002).

\subsection{Tocopherol composition}

Tocopherols are the main lipophilic compounds with antioxidant activity in avocado oil. The antioxidant activity of these compounds is due to the possibility of giving their phenolic hydrogen to free lipid radicals, thus delaying propagation reactions ((Burton and Ingold, 1981; Seppanen et al., 2010). Although $\alpha$-tocopherol is recognized as an important antioxidant (Jiang et al., 2001), Table 6 presented the tocopherol composition of studied avocado oil varieties.

The analysis of the tocopherol fraction by liquid chromatography (HPLC) shows the variability of this fraction from one variety to another. The highest content of total tocopherols is very important in the Fuerte $332.17 \mathrm{mg} / \mathrm{kg}$,
Table 6. $\alpha$-Tocopherol and total Tocopherols of oil from four avocado varieties.

\begin{tabular}{lcl}
\hline & $\begin{array}{l}\alpha \text {-tocopherol } \\
(\mathrm{mg} / \mathrm{kg})\end{array}$ & $\begin{array}{l}\text { Total tocopherols } \\
(\mathrm{mg} / \mathrm{kg})\end{array}$ \\
\hline Ettinger & $46.82 \pm 0.02^{\mathrm{a}}$ & $113.13 \pm 0.03^{\mathrm{a}}$ \\
Fuerte & $177.90 \pm 0.008^{\mathrm{b}}$ & $332.17 \pm 0.02^{\mathrm{b}}$ \\
Hass & $159.80 \pm 0.05^{\mathrm{c}}$ & $252.92 \pm 0.03^{\mathrm{c}}$ \\
Reed & $79.07 \pm 0.01^{\mathrm{d}}$ & $186.14 \pm 0.03^{\mathrm{d}}$ \\
\hline
\end{tabular}

Means of three determinations \pm standard deviation. Values followed by the same small letters in a column are not significantly different at $p<0.05$ according to ANOVA. Tukey HSD test.

followed by the Hass $252.92 \mathrm{mg} / \mathrm{kg}$. On the other hand, tocopherol contents are low in the Reed and Ettinger varieties with values of 186.14 and $113.13 \mathrm{mg} / \mathrm{kg}$, respectively. The variation of tocopherol composition in avocado oils might depend mainly on the geographical conditions and harvest session of the fruits (Flores et al., 2019).

These results are lower than ones reported for olive oil, as the total tocopherol content in olive oils ranges from a few $\mathrm{mg}$ to $450 \mathrm{mg} / \mathrm{kg}$ of oil (Boskou, 2006; Gharby et al., 2013).

The vitamin capacity of tocopherols is related to the content of $\alpha$-tocopherol (vitamin E). This tocopherol is the most common in nature and the most biologically active (Leger, 2000). Indeed, the highest percentage is observed in the Fuerte $(177.9 \mathrm{mg} / \mathrm{kg})$. This value is intermediate compared to those reported for olive oil $\left(96 \mathrm{mg} . \mathrm{kg}^{-1}\right)$ (Kamal-Eldin and Appelqvist, 1996), $120 \mathrm{mg} \cdot \mathrm{kg}^{-1}$ (Kim et al., 2008) and 392 mg. $\mathrm{kg}^{-1}$ (De Leonardis and Macciola, 2012). On the other hand, the Fuerte has a high content of this tocopherol.

\section{Chemometric}

In the present study, the discrimination of avocado oil samples according to the chemical composition of its four varieties. Thus, the distinction between avocado oils extracted from different varieties avocado fruit has been based on variances of the measured contents of fatty acid, sterol, and tocopherol. In other words, chemical composition has been used as a chemical expression in the statistical manners in 

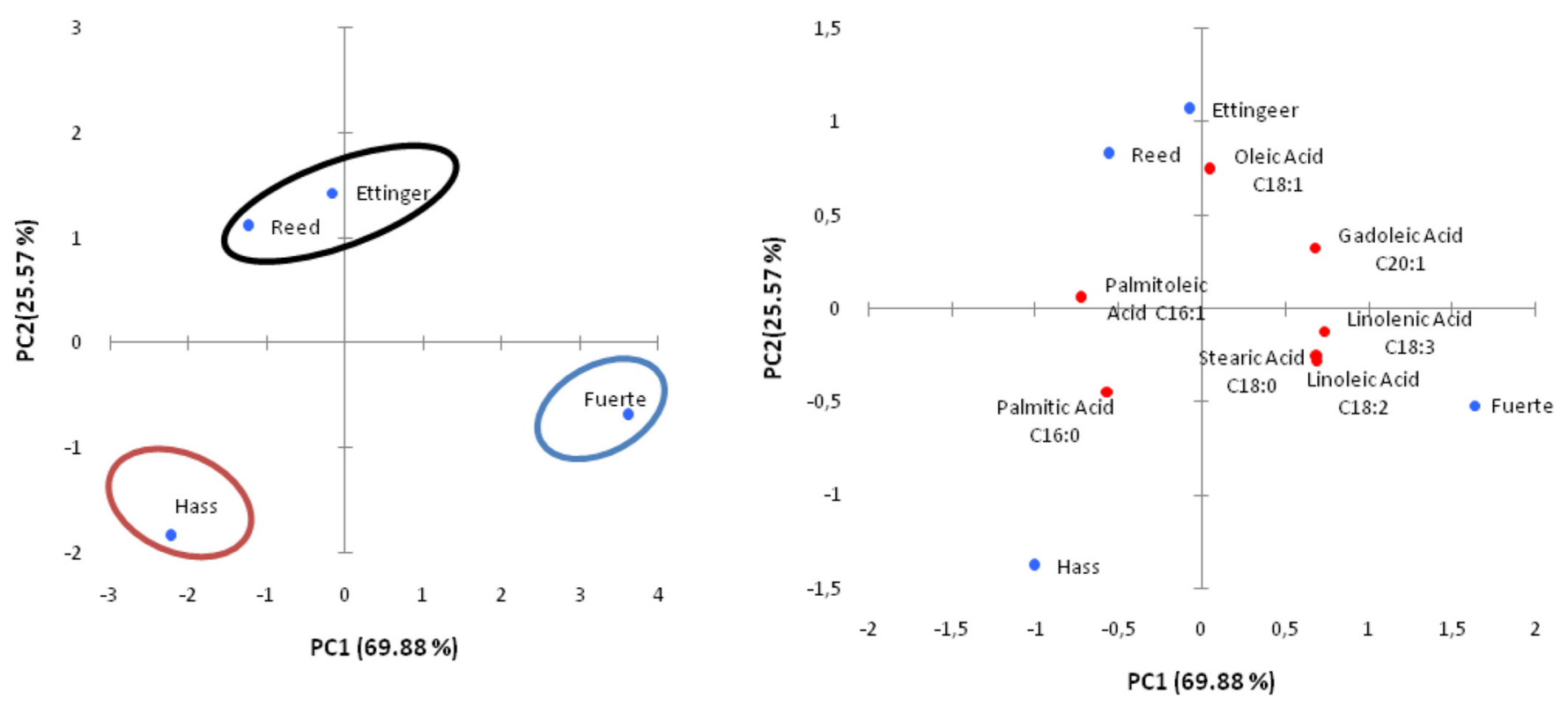

Fig. 1. PCA score plot of the first two principal components (PC1 and PC2; 95.44\% of avocado oil samples from four varieties.

Table 7. Discrimination table for PCA models constructed with fatty acid profile of avocado oil samples from four varieties that explain $95.44 \%$ of total inertia.

\begin{tabular}{llll}
\hline & Eigenvalue & \% Inertia & \% Cumulative inertia \\
\hline PC1 & 4.891 & 69.875 & 69.875 \\
PC2 & 1.79 & 25.566 & 95.441 \\
PC3 & 0.319 & 4.559 & 100 \\
\hline
\end{tabular}

order to determine differences between avocado oil samples to discriminate quality oil. PCA, AHC, and CHAID were used for chemometric treatment, data found were treated in order to establish the variance between avocado oil samples.

\subsection{Principal Component Analysis (PCA)}

To determine correlations between variety and the fatty acid composition of avocado oil, analytical data were undergone to normalize PCA as a statistical manner employing four variables. Two principal components (PC1, PC2) explain $95.44 \%$ of total inertia (Fig. 1). PC1 presents $69.88 \%$ of the total variance of the data, PC2 exhibits $25.57 \%$ of the total variance of the data (Tab. 7).

Left Figure 1 shows three groups, the first one is avocado oil of Ettinger and Reed variety, the second one contains avocado oil of Fuerte variety, while the last one is composed by avocado oil of Hass variety. Right Figure 1 presents the difference in terms of the fatty acid composition of avocado oil of different varieties. The oleic and gadoleic acid content in the avocado oil of Ettinger and Reed variety are close to each other, different from The oleic acid C18:1 and gadoleic acid C20:1 content in the avocado oil of Fuerte and Hass variety. Right Figure 1 also shows stearic, and linoleic acid of avocado oil of Fuerte variety is very different from the other samples.

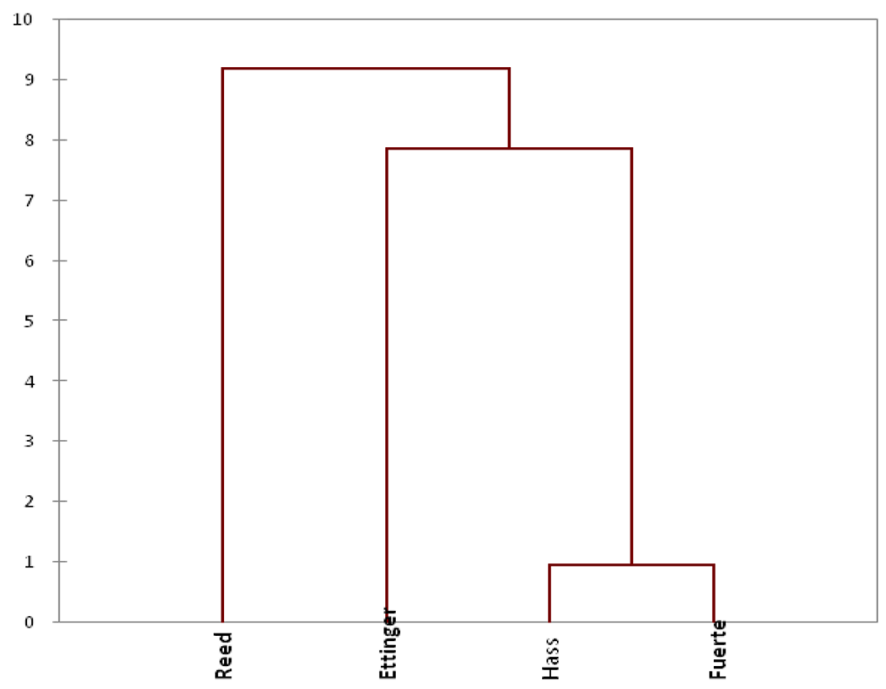

Fig. 2. Dendrograph classification of the avocado oil using the sterol composition, based on four varieties of avocado fruits.

PCA regression model showed successful discrimination avocado oil extracted of different varieties at $95.44 \%$ accuracy level.

\subsection{Agglomerative Hierarchical Clustering (AHC)}

AHC is a strong multivariate exploratory manner popularly employed to identify the (dis)similarity between the $\mathrm{N}$ variables (Mohammed et al., 2019). We tentatively used the sterol composition in avocado oil to distinguish four varieties of avocado fruits. Figure 2 presents the dendrogram of sterol compositions in avocado oil obtained from the 4 evaluated varieties. Two sets were determined. The first set (Fig. 2, left) 


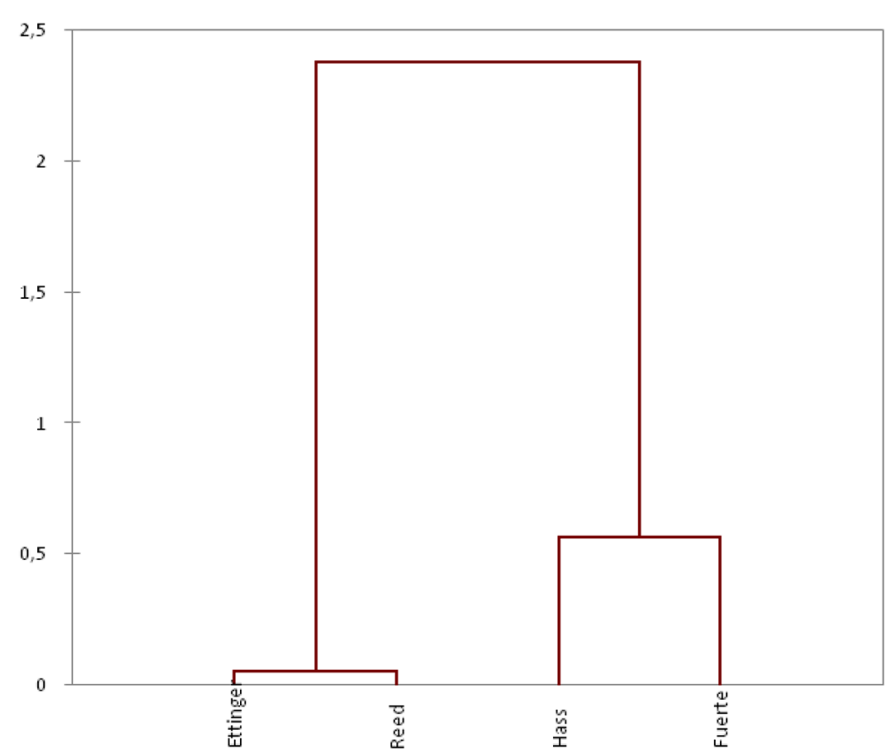

Fig. 3. Dendrograph classification of the avocado oil using the total sterol, based on four varieties of avocado fruits.

comprises the avocado oil of Reed variety. The second set includes two sub-groups, one with avocado oil from Ettinger variety, while the second sub-group contains avocado oil from Hass and Fuerte variety. Particularly, Agglomerative Hierarchical Clustering shows that the sterol content in the avocado oil of Hass and Fuerte variety was close to each other and different compared to the oil of Ettinger and Reed variety.

Figure 3 shows the dendrogram of total sterol content in avocado oil obtained from the 4 varieties. The dating dendrogram (Fig. 3) presented two main sets. One set includes the avocado oil of Ettinger and Reed variety. This set shows less uptake compared to other varieties. The second set is comprised of avocado oil of Hass and Fuerte varieties. This last displays the uptake of total sterol on a higher side. This study reported that AHC analytical was more efficient in unambiguously distinct avocado oils extracted from four different varieties using sterol composition.

\subsection{Classification trees}

Chi-squared Automatic Interaction Detector (CHAID) is a most useful technique at discovering which variables are the most helpful for separating studied samples into known sets. Here, the CHAID manner was used to the 4 varieties avocado fruits using total tocopherol content, providing a model to discriminate between avocado oils extracted from a of avocado fruits. The correct classification rate achieved by CHAID for avocado oil of different fruit varieties is $50 \%$ using total tocopherol content (Tab. 8). The method employed a basic algorithm to built non-binary trees, which depends on the Chisquare test to establish the best split. Figure 4 shows the tree derived from the CHAID model. The small frames contain the node numbers indicate the domain of the variable employed for the split. Regarding avocado oil of Reed and Ettinger varieties, it should be highlighted that the correct distinction rate achieved is $100 \%$, characterized by low values of total
Table 8. Confusion matrix for the classification avocado oil extracted of different avocado fruit varieties.

\begin{tabular}{lllllll}
\hline From $\backslash$ To & Ettinger & Reed & Hass & Fuerte & Total & \% correct \\
\hline Ettinger & 1 & 0 & 0 & 0 & 1 & 100.00 \\
Reed & 0 & 1 & 0 & 0 & 1 & 100.00 \\
Hass & 1 & 0 & 0 & 0 & 1 & 0.00 \\
Fuerte & 1 & 0 & 0 & 0 & 1 & 0.00 \\
Total & 3 & 1 & 0 & 0 & 4 & 50.00 \\
\hline
\end{tabular}
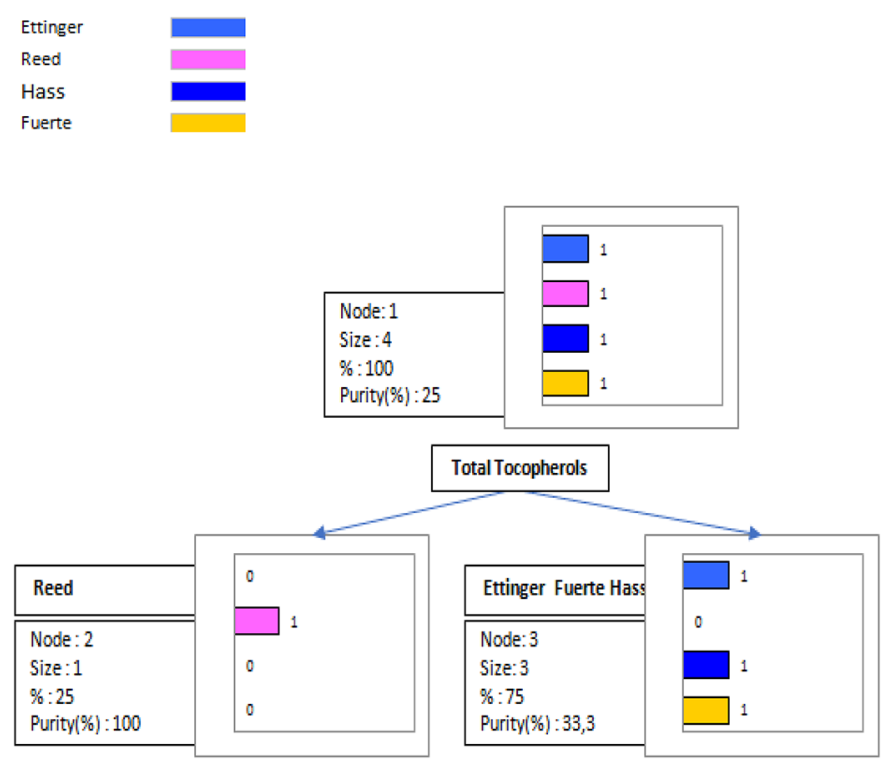

Fig. 4. Classification tree obtained from CHAID for avocado oil samples extracted from different avocado varieties. Inset classification of samples based on total tocopherol content.

tocopherol compared with total tocopherol of avocado oil extracted from Hass, and Fuerte varieties. Avocado oil of Hass variety is characterized by a high content of total tocopherol compared to the avocado oil of of Reed and Ettinger varieties. At last, avocado oil of Fuerte variety is characterized by the highest content values of total tocopherol than other samples (Fig. 4). The big interest of CHAID analysis is owing to the fact that a good classification was realized, although the employ of only a few variables. It is possible to make sure the avocado fruits variety (Reed, Ettinger, Hass, and Fuerte variety), as shown in Figure 4.

\section{Conclusion}

The chemical composition of fatty acids, total sterol and tocopherol varies considerably from one variety to another. Oleic acid, $\beta$-sitosterol, and $\alpha$-tocopherol are the majority of compounds in the four varieties of Avocado studied. A higher percentage of oleic acid $(61.18 \%)$ in oil was obtained for the Reed; besides, a higher content of sterol $(5378.80 \mathrm{mg} / \mathrm{kg})$ and tocopherol $(332.17 \mathrm{mg} / \mathrm{kg})$ was obtained for the Fuerte. This 
reflects the high nutritional value of this oil. it may have important applications as an edible oil for human nutrition and different industrial applications. On the other hand, discrimination avocado fruit varieties carried out using chemometric tools that allowed detaching the set avocado oil dataset, getting accurate discrimination results.

\section{Disclosure of interests}

The authors declare that they have no conflicts of interest related to any portion of the study or the preparation of the manuscript.

Acknowledgment. The authors gratefully acknowledge the help and support of the fellow scientists and colleagues that were involved in this work.

\section{References}

AOCS. 1998. Official Methods and Practices of the AOCS. 5th ed. Champaign, USA: AOCS Press.

Ashton OB, Wong M, McGhie TK, et al. 2006. Pigments in avocado tissue and oil. J Agric Food Chem 54(26): 10151-10158. https:// doi.org/10.1021/jf061809j.

Athar M, Nasir SM. 2005. Taxonomic perspective of plant species yielding vegetable oils used in cosmetics and skin care products. Afr J Biotechnol 4(1): 36-44.

Awad AB, Roy R, Fink CS. 2003. Beta-sitosterol, a plant sterol, induces apoptosis and activates key caspases in MDA-MB-231 human breast cancer cells. Oncol Rep 10(2): 497-500.

Azizi S, Najafzadeh S. 2008. Fatty acids and volatile compounds in avocado cultivated in North of Iran. World Appl Sci J 5(1): 1-4.

Beltran G, Bejaoui MA, Jimenez A, Sanchez-Ortiz A. 2015. Ethanol in Olive Fruit. Changes during Ripening. J Agric Food Chem 63 (22): 5309-5312. https://doi.org/10.1021/acs.jafc.5b01453.

Berasategi I, Barriuso B, Ansorena D, Astiasaran I. 2012. Stability of avocado oil during heating: comparative study to olive oil. Food Chem 132(1):439-446. https://doi.org/10.1016/j.food chem.2011.11.018.

Bora PS, Narain N, Rocha RV, Paulo MQ. 2001. Characterization of the oils from the pulp and seeds of avocado (cultivar: Fuerte) fruits. Grasas Aceites 52(3-4):171-174.

Boskou D. 2006. Olive oil: chemistry and technology. AOCS Publishing.

Boujemaa I, El Bernoussi S, Harhar H, Tabyaoui M. 2020. The influence of the species on the quality, chemical composition and antioxidant activity of pumpkin seed oil. OCL $27: 40$. https://doi. org/10.1051/ocl/2020031.

Burton GW, Ingold KU. 1981. Autoxidation of biological molecules. 1. Antioxidant activity of vitamin $\mathrm{E}$ and related chain-breaking phenolic antioxidants in vitro. J Am Chem Soc 103(21): 64726477. https://doi.org/10.1021/ja00411a035.

Carvajal-Zarrabal O, Nolasco-Hipolito C, Aguilar-Uscanga MG, Melo-Santiesteban G, Hayward-Jones PM, Barradas-Dermitz DM. 2014. Avocado oil supplementation modifies cardiovascular risk profile markers in a rat model of sucrose-induced metabolic changes. Dis Mark 2014: 386425. https://doi.org/10.1155/2014/ 386425.

Codex Alimentarius. 2019. Fao/Who Food Standards Programme Codex Committee on Fats and Oils 26th Session, 2019.

COI/T.5/NC n³/Rév.7. 2012. Norme commerciale applicable aux huiles d'olive et aux huiles de grignons d'olive.
De Leonardis A, Macciola V. 2012. Heat-oxidation stability of palm oil blended with extra virgin olive oil. Food Chem 135(3): 17691776. https://doi.org/10.1016/j.foodchem.2012.06.046.

Denis Loeillet EIaCS. 2008. Dossier du mois : L'avocat (Le Maroc: un nouvel outsider?). FruiTrop Online 159. France: CIRAD.

Flores M, Saravia C, Vergara CE, Avila F, Valdes H, Ortiz-Viedma J. 2019. Avocado oil: Characteristics, properties, and applications. Molecules 24(11): 2172. https://doi.org/10.3390/mole cules24112172.

Gharby S, Harhar H, El Monfalouti H, Kartah B, Guillaume D, Charrouf Z. 2012. Chemical and oxidative properties of olive and argan oils sold on the Moroccan market. A comparative study. Mediterr J Nutr Metab 5: 31-38. https://doi.org/10.1007/ s12349-011-0076-5.

Gharby S, Harhar H, Kartah B, Chafchauni I, Sibawayh Z, Charrouf Z. 2013. Chemical Characterization and oxidative stability of two monovarietal virgin olive oils (Moroccan Picholine and Arbequina) grown in Morocco. J Mater Environ Sci 4(6): 935942.

Gharby S, Harhar H, Boulbaroud S, et al. 2014. The stability of vegetable oils (sunflower, rapeseed and palm) sold on the Moroccan market at high temperature. Int J Chem Biochem Sci 5: 47-54.

Gharby S, Harhar H, Farssi M, Taleb AA, Guillaume D, Laknifli A. 2018. Influence of roasting olive fruit on the chemical composition and polycyclic aromatic hydrocarbon content of olive oil. $O C L$ 25(3): A303.

Gharby S, Ravi HK, Guillaume D, Abert Vian M, Chemat F, Charrouf Z. 2020. 2-methyloxolane as alternative solvent for lipid extraction and its effect on the cactus (Opuntia ficus-indica L.) seed oil fractions. OCL 27: 27. https://doi.org/10.1051/ocl/ 2020021.

Goff SA, Klee HJ. 2006. Plant volatile compounds: sensory cues for health and nutritional value? Science 311(5762): 815-819.

Hurtado-Fernandez E, Fernandez-Gutierrez A, Carrasco-Pancorbo AE. 2018. Exotic Fruits. Avocado fruit-Persea americana. Amsterdam (Netherlands): Elsevier Inc.

Indriyani L, Rohman A, Riyanto S. 2016. Physico-chemical characterization of avocado (Persea americana Mill.) oil from three Indonesian avocado cultivars. Res J Med Plant 10(1):67-78.

ISO 659. 2009. Oilseeds - Determination of oil content (Reference method). Geneva: International Organization for Standardization ISO 659:2009.

ISO 5508. 1990. Animal and vegetable fats and oils analysis by CPG of methyl esters of fatty acids.

ISO 6799. 1991. Determination of the sterol fraction by gas chromatography.

ISO 9936. 2006. Animal fats and vegetable-Determination of tocopherols and tocotrienols by liquid chromatography high performance.

Jiang Q, Christen S, Shigenaga MK, Ames BN. 2001. Gammatocopherol, the major form of vitamin $\mathrm{E}$ in the US diet, deserves more attention. Am J Clin Nutr 74(6): 714-722. https://doi.org/ 10.1093/ajen/74.6.714.

Kamal-Eldin A, Appelqvist LA. 1996. The chemistry and antioxidant properties of tocopherols and tocotrienols. Lipids 31(7): 671-701. https://doi.org/10.1007/BF02522884.

Kim H, Kim S-G, Choi Y, Jeong H-S, Lee J. 2008. Changes in tocopherols, tocotrienols, and fatty acid contents in grape seed oils during oxidation. J Am Oil Chem Soc 85(5): 487-489.

Kim K-B, Nam YA, Kim HS, Hayes AW, Lee B-M. 2014. $\alpha$-Linolenic acid: Nutraceutical, pharmacological and toxicological evaluation. Food Chem Toxicol 70: 163-178. 
Koh H-H, Murray IJ, Nolan D, Carden D, Feather J, Beatty S. 2004. Plasma and macular responses to lutein supplement in subjects with and without age-related maculopathy: a pilot study. Exp Eye Res 79(1): 21-27.

Kosińska A, Karamać M, Estrella I, Hernández T, Bartolomé BA, Dykes GA. 2012. Phenolic compound profiles and antioxidant capacity of Persea americana Mill. peels and seeds of two varieties. J Agric Food Chem 60(18): 4613-4619.

Krumreich FD, Borges CD, Mendonça CRB, Jansen-Alves C, Zambiazi RC. 2018. Bioactive compounds and quality parameters of avocado oil obtained by different processes. Food Chem 257: $376-381$.

Leger C-L. 2000. La vitamine E: état actuel des connaissances, rôle dans la prévention cardio-vasculaire, biodisponibilité. OCL 7(3): 258-265.

Lozano Y, Ratovohery J, Gaydou EM. 1985. Composition en acides gras de différentes variétés d'avocats: évolution au cours du développement physiologique du fruit et incidence de la zone de culture. Rev Fr Corps Gras 32(10): 377-386.

Lu QY, Arteaga JR, Zhang Q, Huerta S, Go VL, Heber D. 2005. Inhibition of prostate cancer cell growth by an avocado extract: role of lipid-soluble bioactive substances. J Nutr Biochem 16(1): 23-30. https://doi.org/10.1016/j.jnutbio.2004.08.003.

Lunn J, Theobald H. 2006. The health effects of dietary unsaturated fatty acids. Nutr Bull 31(3): 178-224.

Mardigan LP, SANTOS VJD, SILVA PTD, Visentainer JV, GOMES STM, Matsushita M. 2019. Investigation of bioactive compounds from various avocado varieties (Persea americana Miller). Food Sci Technol 39: 15-21.

Medina J. 1980. Alguns aspectos tecnológicos das frutas tropicais e seus produtos. São Paulo: Secretaria de Agricultura e Abastecimento de São Paulo.

Mínguez-Mosquera MI, Gandul-Rojas B, Montaño-Asquerino A, Garrido-Fernández J. 1991. Dertermination of chlorophylls and carotenoids by high-performance liquid chromatography during olive lactic fermentation. J Chromatogr A 585(2): 259-266.

Mohammed F, Guillaume D, Dowman S, Abdulwali N. 2019. An easy way to discriminate Yemeni against Ethiopian coffee. Microchem $J$ 145: 173-179.

Mooz ED, Gaiano NM, Shimano MYH, Amancio RD, Spoto MHF. 2012. Physical and chemical characterization of the pulp of different varieties of avocado targeting oil extraction potential. Food Sci Technol 32(2): 274-280.

Moreau RA, Whitaker BD, Hicks KB. 2002. Phytosterols, phytostanols, and their conjugates in foods: Structural diversity, quantitative analysis, and health-promoting uses. Prog Lipid Res 41(6): 457-500.

Moreno AO, Dorantes L, Galindez J, Guzman RI. 2003. Effect of different extraction methods on fatty acids, volatile compounds, and physical and chemical properties of avocado (Persea americana Mill.) oil. J Agric Food Chem 51(8): 2216-2221. https://doi.org/10.1021/jf0207934.

Ojewole JAO, Amabeoku GJ. 2006. Anticonvulsant effect of Persea americana Mill (Lauraceae)(Avocado) leaf aqueous extract in mice. Phytother Res 20 (8): 696-700.

Ojewole J, Kamadyaapa DR, Gondwe MM, Moodley K, Musabayane CT. 2007. Cardiovascular effects of Persea americana Mill (Lauraceae)(avocado) aqueous leaf extract in experimental animals. Cardiovasc J Afr 18(2): 69.

Olaeta J, Gardiazabal F, Martinez O. 1986. Variacin estacional en el contenido de aceite y su relacin con la palatabilidad, en frutos de palto (Persea americana mill). Agric Téc 46 (3): 365-367.
Ortiz-Avila O, Sámano-García CA, Calderón-Cortés E, et al. 2013. Dietary avocado oil supplementation attenuates the alterations induced by type I diabetes and oxidative stress in electron transfer at the complex II-complex III segment of the electron transport chain in rat kidney mitochondria. J Bioenerg Biomembr 45(3): 271-287.

Pearson D. 1975. Seasonal English market variations in the composition of South African and Israeli avocados. J Sci Food Agric 26(2): 207-213. https://doi.org/10.1002/jsfa.2740260211.

Phillips KM, Ruggio DM, Ashraf-Khorassani M. 2005. Phytosterol composition of nuts and seeds commonly consumed in the United States. J Agric Food Chem 53(24): 9436-9445. https://doi.org/

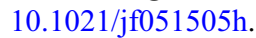

Plaza L, Sanchez-Moreno C, de Pascual-Teresa S, de Ancos B, Cano MP. 2009. Fatty acids, sterols, and antioxidant activity in minimally processed avocados during refrigerated storage. J Agric Food Chem 57(8): 3204-3209. https://doi.org/10.1021/ jf900541r.

Psomiadou E, Tsimidou M. 2001. Pigments in Greek virgin olive oils: occurrence and levels. J Sci Food Agric 81(7): 640-647.

Rabeh A, Maata N, Adlouni A. 2018. Importance of the ethyl esters analysis in improvement of the moroccan extra virgin olive oil quality evaluation. Am J Innov Res Appl Sci 6(5): 235-242.

Rukmini A, Raharjo S. 2010. Pattern of peroxide value changes in virgin coconut oil (VCO) due to photo-oxidation sensitized by chlorophyll. J Am Oil Chem Soc 87(12): 1407-1412.

Sales-Campos H, Reis de Souza P, Crema Peghini B, Santana da Silva J, Ribeiro Cardoso C. 2013. An overview of the modulatory effects of oleic acid in health and disease. Mini-Rev Med Chem 13 (2): 201-210.

Salunkhe DK, Kadam S. 1995. Handbook of fruit science and technology: Production, composition, storage, and processing. CRC Press.

Seppanen CM, Song Q, Saari Csallany A. 2010. The antioxidant functions of tocopherol and tocotrienol homologues in oils, fats, and food systems. J Am Oil Chem Soc 87(5): 469-481.

Soares S, Mancini Filho J, Modesta R. 1992. Sensory detection limits of avocado oil in mixtures with olive oil. Rev Esp Cien Tec Ali 32 (5): 509-516.

Swisher HE. 1988. Avocado oil. J Am Oil Chem Soc 65(11): 1.

Tango J, da Costa S, Antunes A, Figueiredo I. 1969. Composiçâo do fruto e do óleo de diferentes variedades de abacate cultivadas no estado de Sâo Paulo. Coletânea do Instituto de Tecnología de Alimentos 3: 283-292.

Tango JS, Carvalho CRL, Soares NB. 2004. Caracterização física e química de frutos de abacate visando a seu potencial para extração de óleo. Rev Bras Frutic 26(1): 17-23.

Vekiari SA, Papadopoulou PP, Lionakis S, Krystallis A. 2004. Variation in the composition of Cretan avocado cultivars during ripening. J Sci Food Agric 84(5): 485-492.

Wang T, Hicks KB, Moreau R. 2002. Antioxidant activity of phytosterols, oryzanol, and other phytosterol conjugates. $\mathrm{J} \mathrm{Am} \mathrm{Oil}$ Chem Soc 79(12): 1201-1206.

Wang W, Bostic TR, Gu L. 2010. Antioxidant capacities, procyanidins and pigments in avocados of different strains and cultivars. Food Chem 122(4): 1193-1198.

Wood JD, Richardson RI, Nute GR, et al. 2004. Effects of fatty acids on meat quality: A review. Meat Sci 66(1): 21-32. https://doi.org/ 10.1016/S0309-1740(03)00022-6.

Yoshida Y, Niki E. 2003. Antioxidant effects of phytosterol and its components. J Nutr Sci Vitaminol (Tokyo) 49(4): 277-280. https://doi.org/10.3177/jnsv.49.277. 
Youssef NB, Zarrouk W, Carrasco-Pancorbo A, et al. 2010. Effect of olive ripeness on chemical properties and phenolic composition of chétoui virgin olive oil. J Sci Food Agric 90(2): 199-204.
Zhang Z, Huber DJ, Rao J. 2013. Antioxidant systems of ripening avocado (Persea americana Mill.) fruit following treatment at the preclimacteric stage with aqueous 1-methylcyclopropene. Postharvest Biol Technol 76: 58-64.

Cite this article as: Nasri C, Halabi Y, Harhar H, Mohammed F, Bellaouchou A, Guenbour A, Tabyaoui M. 2021. Chemical characterization of oil from four Avocado varieties cultivated in Morocco. OCL 28: 19. 